\title{
Ornithine Decarboxylase and Tyrosine Kinase Activity in Juvenile Polyps of Childhood
}

\author{
Y. ELITSUR, S. J. G. KOH, J. A. MOSHIER, J. DOSESCU, J. TUREAUD, AND A. P. N. MAJUMDAR \\ Department of Pediatrics, Pediatric Gastroenterology Division, Marshall University, Huntington, West \\ Virginia 25701-0195 [Y.E., S.J.G.K.], Departments of Internal Medicine and Molecular Biology and \\ Genetics [J.A.M., J.D.], and Division of Gastroenterology, VA Medical Center [J.T., A.P.N.M.], Wayne \\ State University School of Medicine, Detroit, Michigan 48201
}

\begin{abstract}
2.
Juvenile polyps (JP) are the most common colonic tumor in children. Although considered benign, malignant transformation has been reported in JP. Ornithine decarboxylase (ODC) and tyrosine kinase (TyK) enzymes are markers for a rapid cell proliferation index. DNA aneuploidy score and p53 gene expression are late malignant changes seen in patients with colon cancer. In this study, we investigated ODC and TyK activities as well as DNA aneuploidy score and p53 expression in juvenile polyps compared with the adjacent normal colonic mucosa. Results showed that ODC was significantly increased in JP compared with the adjacent normal colonic mucosa. TyK activity was increased in $3 / 5$ polyps and decreased in 2/5 polyps compared with the mucosa. Mean TyK activity was higher in JP compared with normal mucosa but did not reach significance
\end{abstract}

(707 and $632 \mathrm{pmol} / \mathrm{mg}$ pmol, respectively). Moreover, changes in phosphorylization of TyK proteins was also observed in JP but not in normal mucosa. JP had a normal DNA aneuploidy score and showed no expression of p53 gene. We conclude that JP do not express p53 gene and aneuploidy but had higher activity of ODC and TyK enzymes, suggesting a higher stage of cell proliferation. (Pediatr Res 38: 574-578, 1995)

$\quad$ Abbreviations
ODC, ornithine decarboxylase
TyK, tyrosine kinase
JP, juvenile polyp
RIPA, radioimmunoprecipitation assay

JP are the most common form of colon tumors in children (1). Malignant transformation of such polyps has been reported in patients with inherited premalignant conditions, i.e. familial adenomatous polyposis (2-4), but JP in children without such diseases are considered to be benign. Nevertheless, malignant changes within JP have been anecdotally reported in the domestic and foreign journals (3-10). Moreover, adenocarcinomas of the colon have also been reported in children $(11,12)$.

ODC is the first limiting enzyme in the polyamine biosynthetic pathway (13). Polyamines and ODC are synthesized by all eukaryotic cells and are thought to play a crucial role in proliferation of normal and neoplastic cells in the human gut epithelium (14-18). Thus, ODC has been used as an early marker for cell proliferation index and for early detection of colon cancer $(18,19)$.

TyK are a family of proteins which are widely expressed during cell proliferation, differentiation, and transformation $(20-22)$. Increased ODC activity and TyK activity was re-

Received August 22, 1994; accepted April 25, 1995.

Correspondence and reprint requests: Y. Elitsur, M.D., Department of Pediatrics, Division of Gastroenterology, Marshall University School of Medicine, 1801 Sixth Avenue, Huntington, WV 25701-0195. ported in colon mucosa of patients with adenomatous polyps but not in hyperplastic polyps (23).

Tumorigenesis of human colon is preceded with various intracellular oncogene expression and gene alteration (24). One of the changes occurs on chromosome $17 \mathrm{p}$ where the $\mathrm{p} 53$ gene is located. p53 gene expression may be used as a late marker for colon cancer development. Thus, the expression of the p53 gene and DNA ploidy analysis of JP may further be used to evaluate the potential of such polyps to transform into malignant polyps.

The aim of this study was to compare the relationship between ODC and TyK in JP and normal adjacent mucosa in children who do not have increased risk factors for colon cancer development. In addition JP are examined for their potential malignant transformation by their p53 expression and aneuploidy score.

\section{METHODS}

\section{Children Clinical Data}

A total of 10 children participated in the study. All had fresh rectal bleeding and five showed the polyp radiologically. Polyps were located in the sigmoid (five) and in the rectum (five). 
Children's ages ranged between 1.5 and $17 \mathrm{y}$. In three patients, there was a family history of colon cancer, and two other patients had a positive family history for colon polyps. Two patients had a previous history of JP removal and had more than one polyp removed during endoscopy.

\section{Colon Tissues}

Colonic biopsies and JP were obtained from 10 children who underwent colonoscopy for rectal bleeding. After polypectomy, small pieces of the colonic polyps and adjacent colonic biopsies were quickly frozen and stored at $-70^{\circ} \mathrm{C}$ until analyzed. The polyps and their adjacent colonic biopsies were cleared of any histologically malignant changes. Due to ethical constrains, there was a shortage of control biopsies to complete all studies in each pair. Accordingly, JP and adjacent control pair were used for ODC activity, TyK activity, and TyKphosphorylated protein studies upon samples availability. The study was approved by the local Human Investigational Committee. In other experiments, a total of eight pathologic blocks of JP were examined for p53 expression and DNA ploidy analysis. These specimens had no malignant features on histologic examination.

\section{Biochemical Assays}

ODC assay. ODC activity was determined according to the micro method of Beaven et al. (25), as established in our laboratory (17). Briefly, the cell pellet was homogenized in a buffer containing $50 \mathrm{mM}$ HEPES ( $\mathrm{pH} 7.4), 0.1$ mM EDTA, $0.04 \%$ Brij $35,4 \mathrm{mM}$ DTT, and $0.5 \mathrm{mM}$ pyridoxal $5^{\prime}$ phosphate. Homogenates were centrifuged at $47000 \times g$ for $30 \mathrm{~min}$ at $4^{\circ} \mathrm{C}$, and the supernatants were assayed for ODC activity. The incubation mixture contained $10 \mu \mathrm{l}$ of cell homogenate and $10 \mu \mathrm{l}$ of incubation buffer containing $50 \mathrm{mM}$ HEPES ( $\mathrm{pH} 7.4$ ), $0.1 \mathrm{mM}$ EDTA, and $0.144 \mu \mathrm{Ci}$ of $\mathrm{L}-[1-$ ${ }^{14} \mathrm{C}$ ]ornithine hydrochloride $(58 \mathrm{mCi} / \mathrm{mmol})$. Protein concentration was determined by the method of Bradford using a kit from Bio-Rad according to the manufacturer's instructions.

TyK activity. This was measured according to the method of Dangott et al. (26) as previously described by Majumdar et al. (27). Briefly, tissues were solubilized in RIPA buffer $(20 \mathrm{mM}$

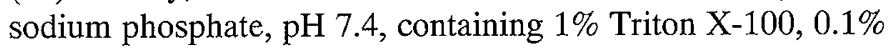
SDS, $0.5 \%$ sodium deoxychloate, $150 \mathrm{mM} \mathrm{NaCl}, 5 \mathrm{mM}$ EDTA, $5 \mathrm{mM}$ phenylmethylsulfonyl fluoride, $1 \mathrm{mM}$ sodium vanadate, $10 \mu \mathrm{g} / \mathrm{ml}$ leupeptin, and $5 \mathrm{mM}$ sodium pyrophosphate and diluted with an equal volume of homogenizing buffer (25). The diluted material was used as a source for the enzyme. The reaction mixture in a final volume of $50 \mu$ l contained 2.5 $\mu \mathrm{mol}$ of Tris- $\mathrm{HCl}, 2 / 5 \mu \mathrm{mol}$ of $\mathrm{MgCl}_{2}, 0.5 \mathrm{nmol}$ of orthovanadate, $0.2 \%$ Triton $\mathrm{X}-100,3 \mu \mathrm{mol}$ of ATP, $0.4 \mu \mathrm{Ci}$ of $\left[\gamma_{-}{ }^{32} \mathrm{P}\right] \mathrm{ATP}$, and $100 \mu \mathrm{g}$ of Glu-Tyr polymer. The reaction at $24^{\circ} \mathrm{C}$ for $10 \mathrm{~min}$ was initiated with a mucosal membrane fraction (10-15 $\mu \mathrm{g}$ of protein) and was terminated by applying $20 \mu \mathrm{l}$ of the reaction mixture onto $3-\mathrm{cm}^{2}$ Whatman No. $3 \mathrm{MM}$ filter paper. The filters were washed extensively in $10 \%$ trichloroacetic acid containing $10 \mathrm{mM}$ sodium pyrophosphate, rinsed with $95 \%$ ethanol, dried, and counted in $5 \mathrm{ml}$ of scintillation mixture. The results were expressed as picomoles of ${ }^{32} \mathrm{P}$ incorporated per $\mathrm{mg}$ of protein.

Autophosphorylation and identification of phosphorylated proteins. This was carried our according to the method of Majumdar et al. $(28,29)$. Briefly, the reaction mixture contained, in a final volume of $50 \mu \mathrm{l}$, the following: $2.5 \mu \mathrm{mol}$ of HEPES (pH 7.8), $2.5 \mu \mathrm{mol}$ of $\mathrm{MgCl}_{2} .0 .5 \mathrm{nmol}$ of orthovanadate, $0.5 \mathrm{nmol}$ of $\left[\gamma_{-}^{32} \mathrm{P}\right] \mathrm{ATP}\left(4 \times 10^{6}\right.$ disintegration $\left./ \mathrm{min}\right)$, and $0.02 \%$ Triton $\mathrm{X}-100$. The reaction at $0-2^{\circ} \mathrm{C}$ for $30 \mathrm{~min}$ was initiated with $75 \mu \mathrm{g}$ of protein and was terminated by adding an equal volume of RIPA lysis buffer $(20 \mathrm{mM}$ sodium phosphate, $\mathrm{pH} 7.4$, containing $1 \%$ Triton $\mathrm{X}-100,0.1 \%$ SDS, $0.5 \%$ sodium deoxycholate, $150 \mathrm{mM} \mathrm{NaCl}, 5 \mathrm{mM}$ EDTA, $5 \mathrm{mM}$ phenylmethylsulfonyl fluoride, $1 \mathrm{mM}$ sodium orthovanadate, $10 \mu \mathrm{g} / \mathrm{ml}$ leupeptin, $5 \mathrm{mM}$ sodium pyrophosphate, and $3 \mu \mathrm{g}$ of antiphosphotyrosine antibody (MAb, Boehringer Mannheim, Indianapolis, IN). After incubation for $3 \mathrm{~h}$ at $4^{\circ} \mathrm{C}$, the immune complex was precipitated with pansorbin (a) and recovered by centrifugation at $10000 \times g$ for $30 \mathrm{~min}$. The immunoprecipitates were dissolved by incubating at $100^{\circ} \mathrm{C}$ for 7 min in a small volume of stopping buffer (62.5 mM Tris-HCl, $\mathrm{pH} 6.8$, $6 \%$ SDS, $20 \%$ glycerol, and $10 \%$ 2-mercaptoethanol)/RIPA lysis buffer (1:1) and centrifuged again. The supernatant was then subjected to SDS-PAGE. After electrophoresis, the gel was fixed, washed, and finally exposed to X-Omat AR film as described previously $(28,30)$. The molecular mass of the labeled bands was calculated from marker proteins run concurrently.

\section{Immunohistologic Study of p53 Suppressor Oncogene Product}

Expression of the p53 suppressor oncogene product was demonstrated by the modified technique of immunoperoxidase methods previously reported (31-33). Commercially available anti-p53 suppressor oncogene product (BP53-12-1) (Biogenix, San Ramon, CA) was used as a marker. Briefly described, the deglycerated tissue sections were treated with 1:20 dilution of anti-p53 protein and 1:40 dilution of horseradish peroxidaseconjugated Ig (Cappal Laboratories, Inc., Cochranville, PA) for 60 and $30 \mathrm{~min}$, respectively. For color reaction, $0.05 \%, 3,3-$ diaminobenzidine tetrachloride (Sigma Chemical Co., St. Louis, MO) was used. Adenocarcinoma from an adult colon was used as a positive control.

\section{DNA Analysis}

The Feulgen-stained slides were analyzed using the CAS 200, a video-based interactive image cytometer (Cell Analysis Systems, Elmhurst, IL) that has been previously described (34). Briefly, after proper calibration, microscopic fields were selected, and the chosen images were digitalized. The integrated optical density of Feulgen-stained nuclei was proved to be proportional to the amount of DNA present in the nuclei. The nuclei of JP were analyzed using the Quantitative Ploidy Analysis soft-ware package (Cell Analysis Systems). The nuclei analyzed were chosen to reflect the typical histopathologic patterns of JP. 
In the DNA histograms produced by the cell image cytometer, JP were classified as diploid if they had a single $G_{0} / G_{1}$ peak. DNA aneuploid would be present if an additional distinct peak was demonstrated different from the diploid peak. The DNA index was calculated as the ratio of the observed peak to the standard peak of $7.18 \mathrm{pg}$ of DNA.

\section{Statistics}

Nonparametrial statistic method, Mann-Whitney statistical analysis, was used in this study. $p<0.05$ was considered as the level of significance.

\section{RESULTS}

ODC activity. A total of seven pairs of JP and histologically normal mucosa were available for ODC determinations. In 6/7 cases, ODC activity was higher in polyp tissue compared with control mucosa (Fig. 1). The mean ODC activities were 356 (range 22-887) and 1145 (range 187-2079) pmol of $\mathrm{CO}_{2} / \mathrm{mg}$ protein/h in normal mucosa and polyp, respectively $(p<0.03)$. For each sample ODC measurement was done in triplicate, and variability was $<10 \%$.

TyK activity and phosphorylation. A total of five pairs of tissue samples were available for determination of TyK activity assay. Although in 3/5 samples TyK activity was higher in the polyp compared to control, no significant difference was achieved. The mean TyK activity was 632 (range 430-1010) and 707 (range 565-821) for normal and polyp tissues, respectively (Fig. 2). Two of the polyp samples with increased TyK activity were also assayed for tyrosine-specific phosphorylation of proteins. Results revealed that, in addition to two prominent 80 - and $70-\mathrm{KD}$ bands, two other bands with molecular masses of 170 and $120 \mathrm{kD}$ were phosphorylated. Extent of tyrosine-specific phosphorylation of these proteins was found to be 2-4-fold in samples from JP when compared with the controls (Fig. 3).

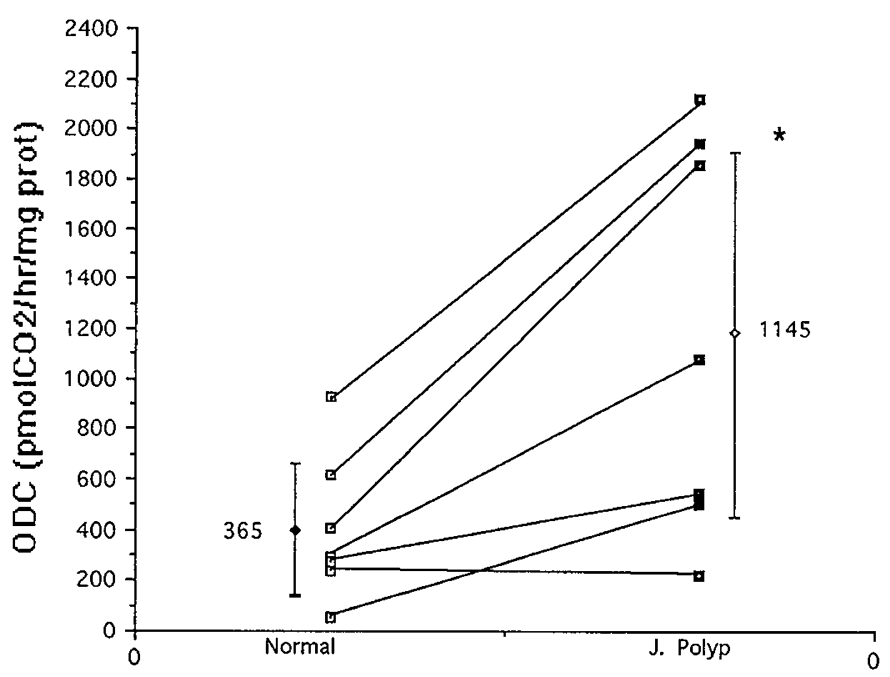

Figure 1. ODC activity in JP and normal mucosa. ODC activity was measured in JP and adjacent normal mucosa as described in Methods. The mean ODC activity was higher in JP compared with adjacent normal mucosa (1145 and $365 \mathrm{pmol}$ of $\mathrm{CO}_{2} / \mathrm{h} / \mathrm{mg}$ of protein, respectively). A total of seven pairs of tissue samples were investigated, each done in triplicate determinations, and variability was $<10 \% .{ }^{*} p<0.05$.

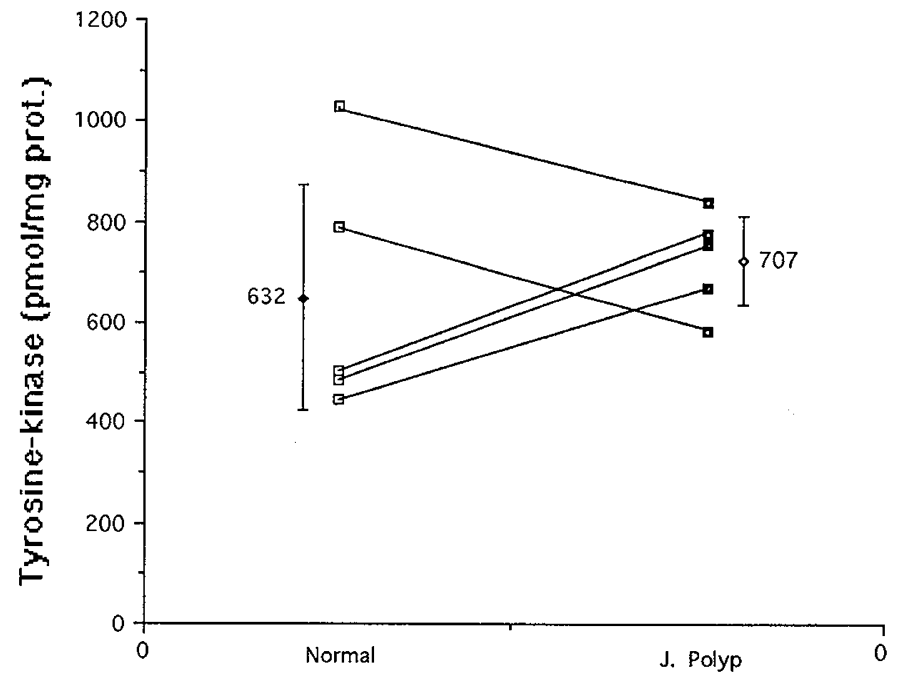

Figure 2. TyK activity in JP and normal mucosa. TyK activity was measured in JP and adjacent normal mucosa as described in Methods. TyK activity in JP tissue was higher than in adjacent normal mucosa in three out of five sample pairs. The mean TyK activity was higher in JP compared with adjacent normal mucosa (707 and $632 \mathrm{pmol} / \mathrm{mg}$ of protein, respectively). A total of five pairs of tissue samples were investigated, each done in triplicate determinations, and variability was $<10 \%$.

p53 and DNA analysis. p53 expression was determined in a total of eight juvenile polyps. No histologic changes of malignant or premalignant features were found in any polyps. p53 was not detected in any of these polyps but was strongly detected in the adenocarcinoma from an adult colon used as a positive control (data not shown). In addition, DNA ploidy showed no abnormal aneuploid peaks (Fig. 4).

\section{DISCUSSION}

Although JP are considered to be benign colonic tumors in children, several reports have suggested that malignant transformation may occur within such polyps $(8,12)$. This histologic transformation should be a concern to the pediatricians and to the pediatric gastroenterologists who are treating these patients. It is estimated that $3-5 \%$ of children with a solitary polyp may develop an adenomatous polyp (35). In a retrospective study Giardiello et al. (8) reported an association of JP (solitary/multiple) and the development of colorectal neoplasia in young age. In a recent report (36), a long-term outcome of patients with solitary JP was investigated. In this survey the authors concluded that the relative risk of dying for patients who have previously had a solitary juvenile polyp in comparison with the general population was similar and, thus, these patients do not require future follow-up.

Unlike ODC activity, TyK activity was similar in JP and normal mucosa. Although TyK and ODC activities are interdependent, they may not share the same intracellular regulatory mechanisms. Our data support this hypothesis. It is clear that, until we dissect the influence of ODC on the signal transduction pathways, we cannot assume that TyK must be activated whenever ODC is increased. It may also be argued that the TyK activity in our study represents the sum activity of many families of enzymes, thus will fail to document a specific 


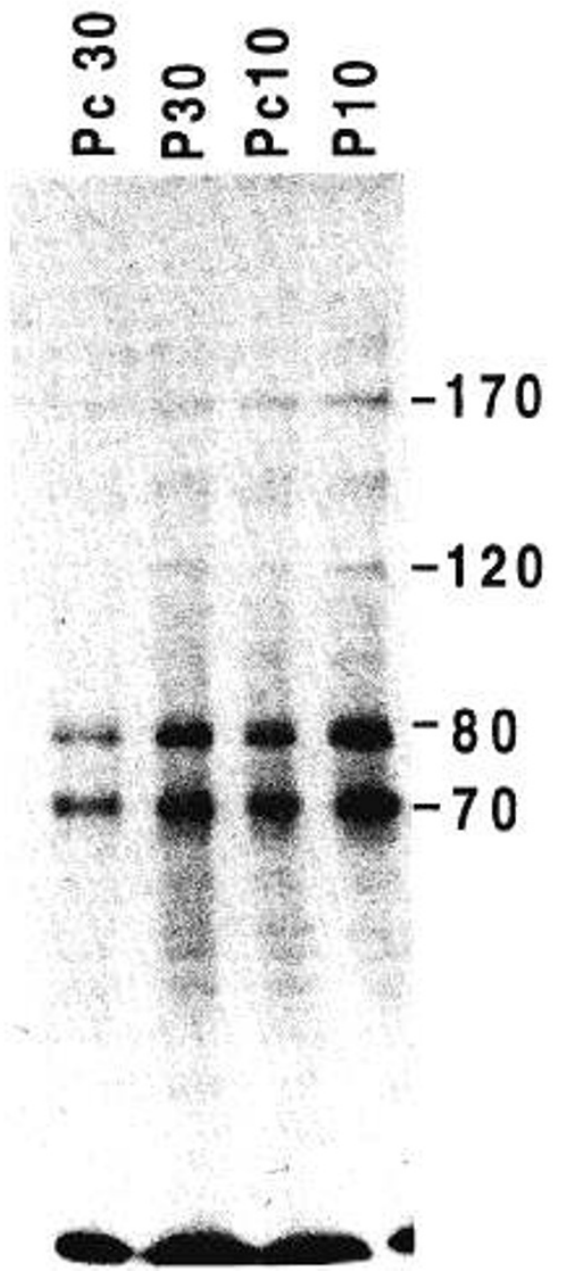

Figure 3. TyK phosphorylation in JP and adjacent normal mucosa. TyKphosphorylated proteins were measured in $2 / 3 \mathrm{JP}$ samples which expressed an increased level of TyK activity. Four different bands were identified (70, 80, 120 , and $170 \mathrm{kD}$ ). These bands showed 2-4-fold higher expression compared with control (P10 vs Pc10 and P30 vs Pc30, respectively). P, JP mucosa; Pc, normal mucosa.

change in a single enzyme. Increased phosphorylation of specific protein seen in JP may support such a hypothesis. Future determination of a specific TyK enzyme is warranted to resolve this enigma.

Colorectal tumorigenesis is a multistep phenomenon which develops through various intracellular chromosomal alterations. The genetic model for this process suggests that several genetic alterations should occur before cancer will be fully expressed $(24,37)$. One of these late changes occurs in the p53 gene, located on chromosome 17 . ODC and TyK expression are secondary markers for a cellular proliferation index and tumor transformations. In this study, we found that the ODC level but not the TyK level is increased in JP compared with adjacent colon mucosa, but these changes were not associated with increased expression of p53 or changes in aneuploidy score. Moreover, we also did not find any histologic markers of premalignant changes in these polyps, i.e. adenomatous changes and metaplasia. We suggest that the increase of enzymatic marker (ODC) in JP reflects its higher stage of proliferation compared with the normal mucosa. Because p53 is a late genetic event in the malignant transformation cascade (24), we
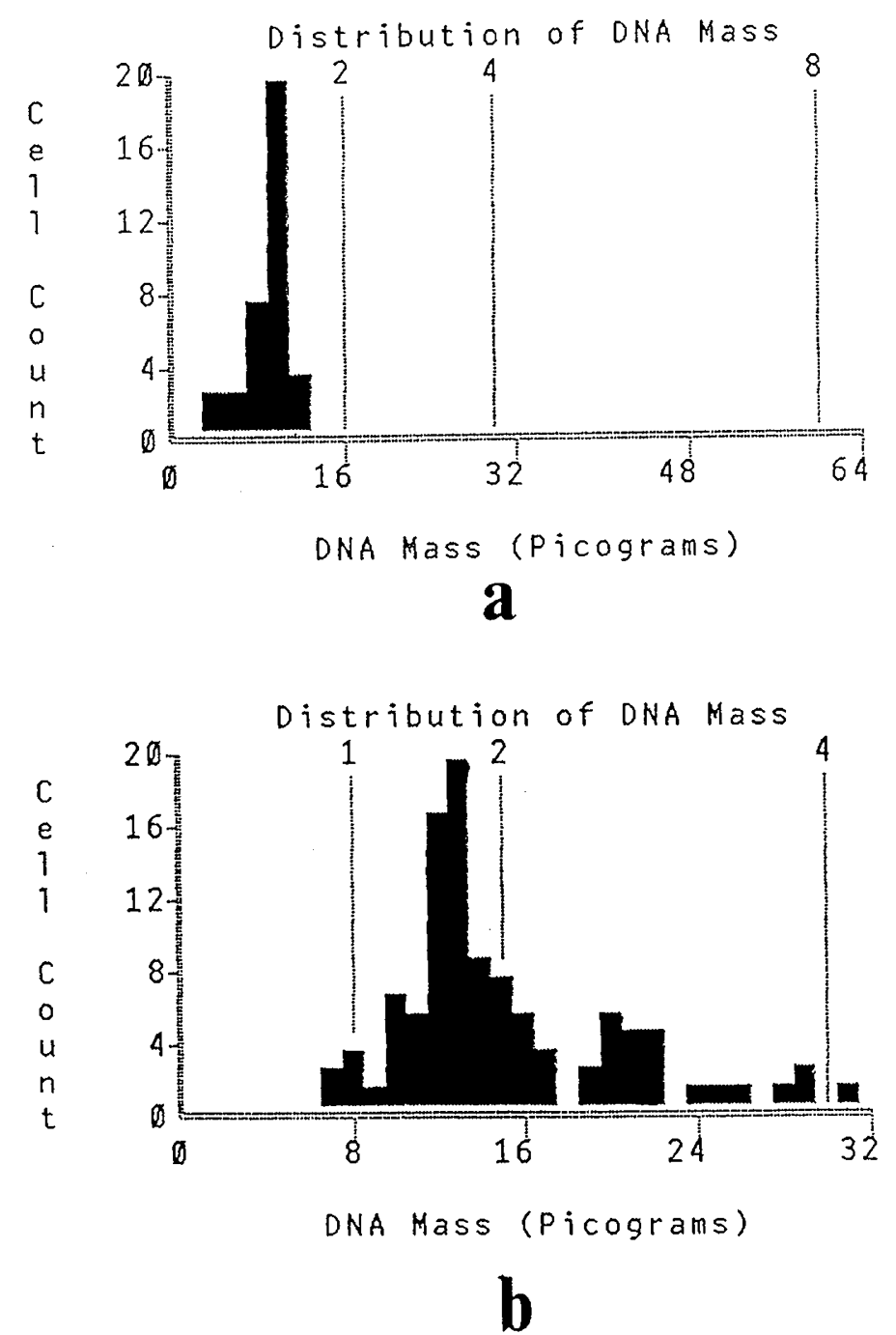

Figure 4. DNA ploidy analysis. DNA ploidy analysis was performed on eight JP histologic blocks as described in Methods. A representative JP sample, which previously expressed higher ODC activity, and TyK activity showed a single DNA peak (a) compared with multiple DNA peaks in colon cancer specimen $(b$, positive control).

speculate that earlier genetic alterations toward malignancy do not occur in the JP. The recent epidemiologic study by Nugent et al. (36) supports this hypothesis.

In summary, in this study, we investigated the potential tumorigenicity of solitary/multiple JP in children by measuring ODC and TyK activity, the late malignant transformation markers, p53 expression, and DNA ploidy score. We report a higher activity of ODC but not TyK in JP compared with normal control, probably reflecting their higher stage of proliferation. There was no evidence of either p53 gene expression or aneuploidy in JP. Further studies, looking at earlier changes in the adenoma-carcinoma sequence to rule out premalignant potential, are warranted.

Acknowledgments. The authors acknowledge the help of Dr. W. B. Triest from the Pathology Department at Cabell Huntington Hospital and the superb secretarial assistant of Jennifer Long. 


\section{REFERENCES}

1. Toccalino H, Guastavino E, DePinni F, O'Donnell JC, Williams M 1973 Juvenile polyps of the rectum and colon. Acta Pediatr Scand 62:337-340

2. Jass JR, Williams CB, Bussey HJR, Morson BC 1988 Juvenile polyposis-a precancerous condition. Histopathology 13:619-630

3. Stemper TJ, Kent TH, Summers RW 1975 Juvenile polyposis and gastrointestinal carcinoma. Ann Intern Med 83:639-646

4. Rosen P, Baratz M 1982 Familial juvenile colonic polyposis with associated colon cancer. Cancer 49:1500-1503

5. Sandler RS, Lipper S 1981 Multiple adenomas in juvenile polyposis. Am J Gastroenterol 75:361-366

6. Grotsky HW, Rickert RR, Smith WD, Newsome JF 1982 Familial juvenile polyposis coli. Gastroenterology 82:494-501

7. Haggitt RC, Pitcock JA 1970 Familial juvenile polyposis of the colon. Cancer $26: 1232-1238$

8. Giardiella FM, Hamilton SR, Kern SE, Offerhaus GJA, Green PA, Celano P, Krush AJ, Booker SV 1991 Colorectal neoplasia in juvenile polyposis or juvenile polyps. Arch Dis Child 66:971-975

9. Friedman $\mathrm{CJ}$, Fechner RE 1982 A solitary juvenile polyp with hyperplastic and adenomatous glands. Dig Dis Sci 27:946-948

10. Tung-hua L, Min-chang C, Hsien-chiu T 1978 Malignant change of juvenile polyp of colon. Chin J 4:434-439

11. Delete in proof

12. Koh SJG, Johnson WW 1986 Cancer of the large bowel in children. South Med J 79:931-935

13. Luk GD, Baylin SB 1983 Polyamines and intestinal growth-increased polyamine biosynthesis after jejunectomy. Am J Physiol 245:G656-G660

14. Russell DH, Durie BGM (eds) 1978 Polyamines as Biochemical Markers of Normal and Malignant Growth. Raven Press, New York, pp 43-58

15. Aurinen M, Paasinen A, Andersson LC, Hollta E 1992 Ornithine decarbosylase activity is critical for cell transformation. Nature 360:355-358

16. Elitsur Y, Gesell M, Luk GD 1993 ODC activity and polyamine levels in isolated human colonocytes. Life Sci 53:945-952

17. Elitsur Y, Moshier JA, Murthy R, Barbish A, Luk GD 1992 Polyamine levels, ornithine decarboxylase (ODC) activity, and ODC mRNA expression in normal and cancerous human colonocytes. Life Sci 50:1417-1424

18. Porter CW, Herrera-Ornelas L, Pera P, Petrelli NF, Mittleman A 1987 Polyamine biosynthetic activity in normal and neoplastic human colorectal tissues. Cancer 60:1275-1281

19. Lamuraglia GM, Lacaine R, Malt RA 1986 High ornithine decarboxylase activity and polyamine levels in human colorectal neoplasia. Ann Surg 204:89-93
20. Bell JC 1988 Mechanisms of transformation by protein-tyrosine kinases. Adv Exp Med Biol 231:475-480

21. Ullich A, Yarden X 1988 Molecular analysis of signal tranduction by growth factors. Biochemistry 27:3114-3119

22. Yarden Y 1988 Growth factor receptor tyrosine kinases. Annu Rev Biochem 57:443478

23. Colarian J, Arlow FL, Calzada R, Luk GD, Majumdar APN 1991 Differential activation of ornithine decarboxylase and tyrosine kinase in the rectal mucosa of patients with hyperplastic and adenomatous polyps. Gastroenterology 100:15281532

24. Fearon ER, Vogelstein B 1990 A genetic model for colorectal tumorigenesis. Cell 61:759-767

25. Beaven MA, Wilcox G, Terpstra GK 1978 A microprocedure for the measurement of ${ }^{14} \mathrm{CO}_{2}$ release from $\left[{ }^{14} \mathrm{C}\right]$ carboxyl-labeled amino acids. Anal Biochem 84:638-641

26. Dangott LJ, Puett D, Melner NH 1986 Characterization of protein tyrosine kinase activity in murine Leydig tumor cells. Biochim Biophys Acta 886:187-194

27. Majumdar APN, Edgerton EA, Arlow FL 1988 Gastric mucosal tyrosine kinase activity during aging and its relationship to cell proliferation in rats. Biochim Biophys Acta 965:97-105

28. Majumdar, APN 1990 Role of tyrosine kinases in gastrin induction of ornithine decarboxylase in colonic mucosa. Am J Physiol 259:G626-G630

29. Majumdar A, Jasti C, Hatfield J, Tureaud J, Fligiel S 1990 Morphological and biochemical changes in gastric mucosa of aged rats. Dig Dis Sci 35:1364-1370

30. Majumdar A, Moshier J, Arlow F, Luk G 1989 Biochemiocal changes in the gastric mucosa after injury in young and aged rate. Biochim Biophys Acta 992:35-40

31. Burns J 1975 Background staining and sensitivity of the unlabelled antibody-enzyme (PAP) method: comparison with the peroxidase labelled antibody sandwich method using Formalin fixed paraffin-embedded material. Histochemistry 43:291-294

32. Koh SJG, Caces JN, Johnson WW 1980 Malignant histiocytic lymphoma in children. Am J Clin Pathol 74:417-426

33. Bartek J, Iggo R, Gannon J, Lane DP 1990 Genetic and immunochemical analysis of mutant p53 in human breast cancer cell lines. Oncogene 5:893-898

34. Bacus JW, Grace LJ 1987 Optical microscope system for standardized cell measurements and analysis. Appl Optics 26:3280-3285

35. Mestre JR 1986 The changing pattern of juvenile polyps. Am J Gastroenterol $81: 312-314$

36. Nugent KP, Talbot IC, Hodgson SV, Phillips RKS 1993 Solitary juvenile polyps: Not a marker for subsequent malignancy. Gastroenterology 105:698-700

37. Hamilton SR 1993 The molecular genetics of colorectal neoplasia. Gastroenterology 105:3-7 